\title{
Distribution, genetic analysis and conservation priorities for rare Texas freshwater molluscs in the genera Fusconaia and Pleurobema (Bivalvia: Unionidae)
}

Lyubov E Burlakova ${ }^{1,2^{*}}$, David Campbell ${ }^{3}$, Alexander Y Karatayev ${ }^{1}$ and Don Barclay ${ }^{4}$

\begin{abstract}
Background: Freshwater bivalves in the order Unionoida are considered to be one of the most endangered groups of animals in North America. In Texas, where over 60\% of unionids are rare or very rare, 15 species have been recently added to the state's list of threatened species, and 11 are under consideration for federal listing. Due to insufficient survey efforts in the past decades, however, primary data on current distribution and habitat requirement for most of these rare species are lacking, thus challenging their protection and management. Taxonomic identification of endemic species based on shell morphology is challenging and complicates conservation efforts. In this paper we present historic and current distributional data for three rare Texas species, Fusconaia askewi, F. lananensis, and Pleurobema riddellii, collected during our 2003-2011 state-wide surveys and suggest appropriate conservation measures. In addition, we tested the genetic affinities of Fusconaia and similar species collected from eastern Texas and western Louisiana using cox 1 and nad 1 sequences.
\end{abstract}

Results: We found that $F$. askewi still inhabits four river basins in eastern and northeastern Texas and can be locally abundant, while $P$. riddellii was found only in one river basin. Pleurobema riddellii was well-separated from F. askewi and grouped with the $P$. sintoxia clade. The sequences for $F$. lananensis were very similar to those for $F$. askewi, with a maximum difference of just over $1 \%$ for nad 1 and only $0.7 \%$ for cox 1 , similar to the variation between $F$. askewi alleles. Except for one low difference (1.55\%) with the partial cox 1 sequence for $F$. burkei, all other Fusconaia populations, including those from the Calcasieu drainage, differed by over $2.3 \%$ for both genes.

Conclusions: Our study suggested that F. lananensis is not a valid species, and it is likely that only one Fusconaia species ( $F$. askewi or its probable senior synonym $F$. chunii) is currently present in East Texas, thus simplifying conservation efforts. Distribution range of both these regional endemics ( $F$. askewi and $P$. riddellii) has been reduced in the last 80 years.

Keywords: Freshwater molluscs, Fusconaia askewi, Fusconaia lananensis, Pleurobema riddellii, Molecular identification, Taxonomy, Distribution, Habitat requirements, Conservation priorities

\footnotetext{
* Correspondence: burlakle@buffalostate.edu

${ }^{1}$ Great Lakes Center, Buffalo State College, 1300 Elmwood Ave, Buffalo, NY 14222, USA

${ }^{2}$ The Research Foundation of The State University of New York, Buffalo State College, Office of Sponsored Programs, Buffalo, NY 14222, USA

Full list of author information is available at the end of the article
} 


\section{Background}

Molluscs are among the most threatened groups of animals on the planet [1], and freshwater bivalves in the order Unionoida are considered to be one of the most endangered groups of animals in North America [2-4]. Our long-term state-wide study of Texas mussels revealed that $65 \%$ of all Texas unionid species are rare, including all state and regional endemics, and most endemic species are very rare [5]. Being one of the top states in species diversity and endemism, Texas ranks fourth in terms of the number of species extinctions [6]. Damming, pollution, water extraction, and urban development have all negatively affected the freshwaters of Texas [7]. Fifteen rare freshwater mussel species were recently added to the state's list of threatened species [8], and 11 of those are currently under consideration for federal listing by the U. S. Fish and Wildlife Service $[9,10]$.

Biodiversity is a fundamental component of evolutionary potential, and species are the primary targets of the U.S. Endangered Species Act. Conservation laws and methods cannot be implemented until the endangered organism is properly clarified and its geographical range is known $[11,12]$. In particular, some of these rare species, Fusconaia flava (Rafinesque), F. askewi (Marsh), and F. lananensis Frierson, are currently reported from several drainages west of the Mississippi [13-15], but identifying specimens using shell morphology is challenging. Morphological variation in Fusconaia in the lower Mississippi drainage is especially complex [16]. Burdick and White [17] reported an unusual genetic type in Fusconaia from the northern and western Ozark region, which could represent a northern extension of F. askewi. Pleurobema riddellii (Lea) can also be very similar in shell features to $F$. askewi [16]. Johnson [18] synonymized $F$. askewi with $F$. flava (under the name F. undata).

In light of the difficulties, we used genetic data as an additional line of evidence. We sampled Fusconaia and similar species from river systems in eastern Texas and western Louisiana to test the genetic affinities of the species, using cox 1 and nad1 sequences. In this paper we describe the geographical distribution and habitat requirements of rare Fusconaia spp. and P. riddellii and results of molecular genetic analyses to define their biogeography, proper taxonomic status, and suggest appropriate conservation measures.

\section{Methods}

\section{Field surveys}

In this manuscript we use results of our state-wide survey of unionids in Texas, USA (latitudes 33 $50^{\prime}-26^{\circ} 56^{\prime}$, longitudes $102^{\circ} 08^{\prime}-93^{\circ} 31^{\prime}$ ) from 2003 to $2011[5,19]$. Mussels were surveyed at 463 sub-sites that were pooled into141 major sites, distributed among 66 waterbodies belonging to 11 major drainages in Texas. The study was carried out with an appropriate Scientific Research Permit issued by the Texas Parks and Wildlife Department (TPWD), and landowner permission for wildlife research was acquired from each property owner before entering their property, if the land was privately owned. Abiotic parameters (physical and chemical) were recorded at the sites using a HACH Hydrolab Quanta, measured parameters included: temperature $\left({ }^{\circ} \mathrm{C}\right), \mathrm{pH}$, total dissolved solids $(\mathrm{g} / \mathrm{L})$, conductivity $(\mu \mathrm{S} / \mathrm{cm})$, and turbidity (ed. NTU). In addition, we recorded depth and the dominant substrate type using the following classification by particle size: bedrock; large boulders $(>45 \mathrm{~cm})$; boulders (>25 - $45 \mathrm{~cm})$; cobble $(>6-25 \mathrm{~cm})$; gravel $(>6-60 \mathrm{~mm})$; sand $(0.06-6 \mathrm{~mm})$; mud/silt $(<0.06 \mathrm{~mm})$. Substrates in sampled East Texas sites were represented by sand (32\%), sand and gravel (21\%), silt (15\%), clay (6\%), and combinations of these. Unionid sampling was conducted via hand collection of both live and dead mussels, by wading in shallow water and by snorkeling. Due to poor water visibility, tactile searches (running fingers over the sediment, usually up to $15 \mathrm{~cm}$ deep, depending on substrate type) were used at all sites. Timed searches were used to detect the presence of mussels and species diversity [20,21] at each site, and if mussel assemblages were present, quantitative methods (from 5 to 28 randomly placed $0.25 \mathrm{~m}^{2}$ quadrats at a site, in average 9 quadrats covering area of $3.75 \mathrm{~m}^{2}$ ), or area -constrained searches (area searched were from 4 to $66 \mathrm{~m}^{2}$ ) were used for assessments of density [22,23]. Relative species abundance was calculated as a percentage of live specimens belong to this species collected at a site from the total number of all live mussels found at the same site, and used as an indicator of the species' dominance in mussel assemblages. Collected mussels were identified based on shell morphology, counted, measured with calipers to the nearest $\mathrm{mm}$, and then carefully rebedded into the sediment from which they were taken. Ten specimens of Fusconaia sp. from the Neches drainage and 5 from the Sabine drainage were sequenced for cox1. Five Fusconaia specimens from the Neches drainage (including one not amplified for cox1) and 3 from the Sabine drainage were sequenced for nad1. Two specimens of $P$. riddellii from the Neches drainage were sequenced for $\operatorname{cox} 1$, with one of them also sequenced for nad1. Voucher specimens were deposited in the Great Lakes Center (Buffalo State College) Invertebrate Collection, in the North Carolina State Museum of Natural Sciences (Raleigh, NC), and in the Invertebrate Zoology Collection of the National Museum of Natural History (Smithsonian Institution, Washington, D.C.). All Fusconaia species identified during our study (F. askewi and F. lananensis) and historical data reported from East Texas (F. askewii [24,25], F. askewi [15,26-30], F. flava [15], F. lananensis [31-33], Quadrula askewi [34,35], Q. askewii [25], Q. chunii [25,35], Q. flava nasuta [34], Q. lananensis 
[25,34,36], Q. undata chunii [34], Unio askewii [24], U. cerinus [24,37], $U$. chunii [24,37,38], were considered to be F. askewi. For justification see sections "Genetic analysis" in Results and Discussion.

\section{Genetic analysis}

Specimens were preserved in ethanol in the field. DNA extraction used Qiagen DNA extraction kits. Portions of the cox 1 and nad1 genes were amplified. Primers for cox1 were 5'-GTTCCACAAATCATAAGGATATTGG3 ' and 5'-TACACCTCAGGGTGACCAAAAAACCA-3', adapted from Folmer et al. [39] and primers for nadh1 were 5'-TGGCAGAAAAGTGCATCAGATTTAAGC-3' and 5'-GCTATTAGTAGGTCGTATCG-3' [40,41]. The primer LoGlyR (5'-CCTGCTTGGAAGGCAAGTGT ACT-3') [42] served as an alternate reverse primer for nadh1. The forward primer UNIOCOII.2 from Walker et al. [43] and/or the reverse primer HCOout (CCAGG TAAAATTAAAATATAAACTTC [44]) provided good amplification for $\operatorname{cox} 1$ for some species. PCR cycles were: $92^{\circ} \mathrm{C} 2 \mathrm{~min} ; 92^{\circ} \mathrm{C} 40$ sec $40^{\circ} \mathrm{C} 40$ sec $72^{\circ} \mathrm{C} 90$ sec $5 \mathrm{x}$; $92^{\circ} \mathrm{C} 40 \mathrm{sec} 50^{\circ} \mathrm{C} 40 \mathrm{sec} 72^{\circ} \mathrm{C} 90 \mathrm{sec} 25 \mathrm{x} ; 72^{\circ} \mathrm{C} 10 \mathrm{~min}$; hold $4^{\circ} \mathrm{C}$. PCR products were purified using Qiagen QIAquick PCR purification kits and, if necessary, Qiagen gel extraction kits. Cycle sequencing used ABI Big Dye Terminator kits with thermal cycle parameters of $1^{\circ} \mathrm{C}$ per second ramp speed, starting with $1 \mathrm{~min}$ at $96^{\circ} \mathrm{C}$ followed by 26 cycles of $96^{\circ} \mathrm{C}$ for $10 \mathrm{sec}, 49^{\circ} \mathrm{C}$ for $5 \mathrm{sec}$, and $60^{\circ} \mathrm{C}$ for $4 \mathrm{~min}$, then $10 \mathrm{~min}$ at $60^{\circ} \mathrm{C}$ and hold at $4^{\circ} \mathrm{C}$. The cycle sequencing products were purified with Qiagen DyeEx kits and then run on an automated sequencer.

The results for each strand were compared and aligned using BioEdit [45]. We analyzed the sequences, along with previously published sequences for other representatives of Pleurobemini with TNT [46]. An Additional file 1 contains sequences used for genetic analysis [see Additional file 1]. Maximum parsimony analyses used 500 random replicates, using all the "new technology" methods (sectorial searching, ratchet, drift, and tree fusing), which greatly speed up the process of finding optimal trees over older approaches [46]. Jackknife analyses used 500 replicates, each using a random "new technology" parsimony search of 10 replicates.

\section{Results}

\section{Genetic analysis}

The sequences for $F$. lananensis were very similar to those for F. askewi, with less than 1\% difference, similar to the variation between $F$. askewi alleles (Tables 1, 2). However, the sequences for $F$. askewi from the Sabine and Neches drainages differed from all other Fusconaia species by over $2.3 \%$ for both genes, except for the partial cox 1 sequence for $F$. burkei. In particular, the cox 1 sequences differed by no more than $0.7 \%$ between $F$. askewi and $F$. lananensis, typical of within-species variation, but differed by a minimum of over $2.5 \%$ from all other Fusconaia sequences, except the short sequence for F. burkei, fairly normal for species-level differences. The cox 1 sequences from putative $F$. askewi from the Calcasieu River system in Louisiana [47] differed from sequences for F. flava and F. cerina by less than $2 \%$ and in most cases by less than 1\% (Table 1). One published sequence for F. flava (AF231733, [48] was identical to one of the Calcasieu sequences. Figures 1, 2 and 3 show the phylogenetic analyses. Jackknife percentages close to 100 show strong support for a particular group. As cladograms, their branching sequence provides the important information. Thus, in Figure 1, Pleurobema (Sintoxia) riddellii 186TS is modestly supported (51\%) as being most closely related to the strongly supported (100\%) group including P. (Sintoxia) sintoxia, P. (Sintoxia) cordatum, and P. (Sintoxia) rubrum. Those four in turn are most closely related to the group of the three Pleuronaia species. However, this association of Pleuronaia and P. (Sintoxia) received less than 50\% jackknife support and was not supported by all of the analyses. The two Fusconaia lananensis have good support (84\%) as being each other's closest relative, and there is very strong support (100\%) for a group including the Sabine and Neches $F$. askewi as well as F. lananensis. In turn, this F. askewi-lananensis group has fairly good support (78\%) as being most closely related to the group including F. masoni, F. cerina, F. flava, the putative F. askewi from the Calcasieu, F. burkei, and F. escambia. The Calcasieu Fusconaia specimens are strongly supported (92\%) as being most closely related to $F$. flava. In Figure 2, P. riddelli again appears to be most closely related to $P$. rubrum, $P$. sintoxia, and $P$. cordatum 2572, but yet again this result is not well-supported. Multiple branches coming from a single vertical line indicates that the relationship among those branches is unresolved. Figure 2 shows strong support (95\%) for a group including the Sabine and Neches F. askewi and the F. lananensis specimens, but does not tell anything about relationships among those eight sequences. Relationships among the different groups within Fusconaia are not well-resolved in Figure 2. Similarly, Figure 3 has strong support (99\%) for a group of all of the F. lananensis and Sabine and Neches F. askewi, but apart from strong support (99\%) for a group of F. askewi Sab1 and Sab2, does not support any particular relationships within that group. Again, $P$. riddellii receives weak support as being most closely related to $P$. sintoxia, P. rubrum, and P. cordatum.

\section{Distribution, densities, size structure, and habitat Fusconaia askewi}

A total of 931 live individuals was collected during our surveys (including 774 mussels originally identified as F. askewi and 157 identified as F. lananensis) at 25 sites 
Table 1 Percent differences in cox 1 sequence for Fusconaia species

\begin{tabular}{|c|c|c|c|c|c|c|c|c|c|c|}
\hline & $\begin{array}{c}\text { F. askewi } \\
3392\end{array}$ & $\begin{array}{l}\text { F. askewi } \\
3395\end{array}$ & $\begin{array}{l}\text { F. askewi } \\
\text { Sab1 } 2\end{array}$ & $\begin{array}{l}\text { F. askewi } \\
\text { Sab3 }\end{array}$ & $\begin{array}{l}\text { F. askewi } \\
\text { Sab4 }\end{array}$ & $\begin{array}{l}\text { F. askewi } \\
\text { Sab5 }\end{array}$ & $\begin{array}{l}\text { F. askewi } \\
\text { TS131 } 133\end{array}$ & $\begin{array}{l}\text { F. askewi } \\
\text { TS166 }\end{array}$ & $\begin{array}{c}\text { F. askewi } \\
\text { TS233 } \\
130204\end{array}$ & \\
\hline F. askewi 3395 & 0.16 & & & & & & & & & \\
\hline F. askewi Sab1 2 & 3.94 & 4.12 & & & & & & & & \\
\hline F. askewi Sab3 & 4.23 & 4.41 & 0.36 & & & & & & & \\
\hline F. askewi Sab4 & 4.48 & 4.68 & 0.57 & 0.19 & & & & & & \\
\hline F. askewi Sab5 & 4.03 & 4.23 & 0.59 & 0.20 & 0.39 & & & & & \\
\hline F. askewi TS131, 133 & 4.08 & 4.24 & 0.35 & 0.54 & 0.57 & 0.59 & & & & \\
\hline F. askewi TS166 & 2.72 & 2.64 & 0.53 & 0.55 & 0.60 & 0.32 & 0.43 & & & \\
\hline $\begin{array}{l}\text { F. askewi TS233 } \\
130204\end{array}$ & 3.73 & 3.91 & 0.35 & 0.18 & 0.19 & 0.20 & 0.30 & 0.22 & & \\
\hline F. burkei & 2.47 & 2.69 & 2.51 & 3.07 & 3.05 & 3.48 & 2.93 & 1.55 & 2.70 & \\
\hline F. cerina & 1.16 & 1.54 & 4.49 & 4.80 & 5.09 & 4.65 & 4.59 & 3.57 & 4.26 & \\
\hline F. cerina LA & 0.66 & 0.92 & 3.76 & 4.04 & 4.29 & 3.83 & 3.76 & 2.87 & 3.44 & \\
\hline F. cor & 4.77 & 4.65 & 4.88 & 5.20 & 5.53 & 5.53 & 5.03 & 4.05 & 4.85 & \\
\hline F. cor 2606 & 4.60 & 4.55 & 4.71 & 5.02 & 5.34 & 5.33 & 4.92 & 3.97 & 4.75 & \\
\hline F. cuneolus & 4.26 & 4.24 & 3.60 & 3.88 & 3.91 & 3.85 & 3.94 & 2.65 & 3.62 & \\
\hline F. escambia & 10.37 & 10.63 & 10.03 & 10.63 & 10.61 & 10.84 & 10.40 & 7.39 & 10.40 & \\
\hline F. flava H1681 & 0.16 & 0.47 & 3.76 & 4.04 & 4.28 & 3.82 & 3.73 & 2.55 & 3.40 & \\
\hline F. flava MO & 0.33 & 0.61 & 3.94 & 4.23 & 4.48 & 4.03 & 3.92 & 2.86 & 3.59 & \\
\hline F. flava 1 & 0.66 & 0.62 & 4.14 & 4.62 & 4.91 & 4.46 & 4.13 & 2.92 & 3.97 & \\
\hline F. hebetata? Ff8 & 3.73 & 4.14 & 3.32 & 3.42 & 3.68 & 3.07 & 3.39 & 3.73 & 3.00 & \\
\hline F. hebetata? Ff9 & 3.09 & 3.56 & 3.56 & 3.90 & 4.20 & 3.87 & 3.59 & 3.99 & 3.20 & \\
\hline $\begin{array}{l}\text { F. lananensis } \\
\text { TS129 } 132179203\end{array}$ & 3.73 & 3.91 & 0.70 & 0.54 & 0.57 & 0.59 & 0.61 & 0.43 & 0.30 & \\
\hline F. masoni & 2.51 & 2.78 & 3.58 & 3.48 & 3.69 & 3.62 & 3.44 & 2.87 & 3.12 & \\
\hline F. ozarkensis & 4.24 & 4.22 & 4.32 & 4.62 & 4.90 & 4.87 & 4.41 & 3.79 & 4.08 & \\
\hline F. ozarkensis 3501 & 4.76 & 4.70 & 4.87 & 5.18 & 5.50 & 5.50 & 4.89 & 4.02 & 4.57 & \\
\hline F. subrotunda 1554 & 4.25 & 4.39 & 4.52 & 4.82 & 5.11 & 4.67 & 4.42 & 3.56 & 4.42 & \\
\hline F. subrotunda PA I & 4.07 & 4.56 & 4.33 & 4.62 & 4.91 & 4.67 & 4.59 & 3.79 & 4.59 & \\
\hline \multirow[t]{2}{*}{ F. subrotunda PA s } & 4.77 & 4.87 & 4.88 & 4.80 & 5.09 & 4.87 & 4.41 & 3.55 & 4.40 & \\
\hline & F. burkei & F. cerina & $\begin{array}{l}\text { F. cerina } \\
\text { LA }\end{array}$ & F. cor & $\begin{array}{l}\text { F. cor } \\
2606\end{array}$ & F. cuneolus & F. escambia & $\begin{array}{l}\text { F. flava } \\
\text { H1681 }\end{array}$ & F. flava MO & F. flava 1 \\
\hline F. cerina & 3.15 & & & & & & & & & \\
\hline F. cerina LA & 2.69 & 1.24 & & & & & & & & \\
\hline F. cor & 4.36 & 4.83 & 4.65 & & & & & & & \\
\hline F. cor 2606 & 4.36 & 4.59 & 4.39 & 0.17 & & & & & & \\
\hline F. cuneolus & 4.11 & 4.27 & 4.08 & 2.55 & 2.25 & & & & & \\
\hline F. escambia & 8.61 & 11.68 & 10.63 & 11.53 & 11.53 & 11.23 & & & & \\
\hline F. flava $\mathrm{H} 1681$ & 2.24 & 0.95 & 0.48 & 4.47 & 4.22 & 3.91 & 10.13 & & & \\
\hline F. flava MO & 2.24 & 1.23 & 0.61 & 4.65 & 4.39 & 4.08 & 10.13 & 0.16 & & \\
\hline F. flava 1 & 2.69 & 1.56 & 0.93 & 4.82 & 4.44 & 4.14 & 10.11 & 0.48 & 0.62 & \\
\hline F. hebetata Ff8 & 2.99 & 3.41 & 3.76 & 5.09 & 5.16 & 4.55 & 9.52 & 3.33 & 3.76 & 4.22 \\
\hline F. hebetata Ff9 & 2.38 & 2.82 & 3.18 & 4.43 & 4.54 & 4.15 & 8.84 & 2.73 & 3.18 & 3.62 \\
\hline $\begin{array}{l}\text { F. lananensis } \\
\text { TS129132179 } 203\end{array}$ & 2.93 & 4.26 & 3.44 & 4.85 & 4.74 & 3.61 & 10.67 & 3.40 & 3.59 & 3.97 \\
\hline
\end{tabular}


Table 1 Percent differences in cox1 sequence for Fusconaia species (Continued)

\begin{tabular}{|c|c|c|c|c|c|c|c|c|c|c|}
\hline F. masoni & 2.24 & 3.12 & 2.47 & 4.65 & 4.55 & 4.40 & 9.89 & 2.24 & 2.47 & 2.82 \\
\hline F. ozarkensis & 3.39 & 4.25 & 3.90 & 4.84 & 4.57 & 4.25 & 10.91 & 3.89 & 3.90 & 4.28 \\
\hline F. ozarkensis 3501 & 3.84 & 4.73 & 4.38 & 5.37 & 5.07 & 4.73 & 11.16 & 4.38 & 4.38 & 4.77 \\
\hline F. subrotunda 1554 & 3.64 & 4.59 & 4.24 & 3.95 & 4.06 & 4.08 & 10.13 & 3.90 & 4.23 & 4.46 \\
\hline F. subrotunda PA I & 3.40 & 4.59 & 4.41 & 3.59 & 4.07 & 4.25 & 10.13 & 3.90 & 4.40 & 4.46 \\
\hline \multirow[t]{2}{*}{ F. subrotunda PA s } & 4.10 & 5.07 & 4.72 & 3.95 & 4.06 & 4.24 & 10.91 & 4.39 & 4.71 & 4.95 \\
\hline & $\begin{array}{c}\text { F. } \\
\text { hebetata } \\
\text { Ff8 }\end{array}$ & $\begin{array}{c}\text { F. } \\
\text { hebetata } \\
\text { Ff9 }\end{array}$ & $\begin{array}{c}\text { F. lananensis } \\
\text { TS129 } 132 \\
179203\end{array}$ & F. masoni & F. ozarkensis & $\begin{array}{c}\text { F. } \\
\text { ozarkensis } \\
3501\end{array}$ & $\begin{array}{c}F . \\
\text { subrotunda } \\
1554\end{array}$ & $\begin{array}{c}\text { F. } \\
\text { subrotunda } \\
\text { PA I }\end{array}$ & & \\
\hline F. hebetata Ff9 & 1.30 & & & & & & & & & \\
\hline $\begin{array}{l}\text { F. lananensis } \\
\text { TS129 } 132179203\end{array}$ & 3.00 & 3.20 & & & & & & & & \\
\hline F. masoni & 2.99 & 2.41 & 3.43 & & & & & & & \\
\hline F. ozarkensis & 4.15 & 3.57 & 4.40 & 3.58 & & & & & & \\
\hline F. ozarkensis 3501 & 4.54 & 3.95 & 4.89 & 4.06 & 0.46 & & & & & \\
\hline F. subrotunda 1554 & 4.36 & 4.16 & 4.42 & 3.91 & 4.24 & 4.72 & & & & \\
\hline F. subrotunda PA I & 4.76 & 4.17 & 4.59 & 3.76 & 4.41 & 4.89 & 1.24 & & & \\
\hline F. subrotunda PA s & 4.75 & 4.35 & 4.40 & 4.23 & 4.72 & 5.21 & 1.23 & 1.24 & & \\
\hline
\end{tabular}

in 17 East Texas counties (Anderson, Angelina, Cherokee, Hardin, Harrison, Houston, Jasper, Leon, Nacogdoches, Panola, Rusk, San Augustine, Shelby, Smith, Titus, Tyler, and Upshur) (Table 3, Figure 4B). We found F. askewi in four drainages (Neches, Trinity, Sabine, and Red river basins) in eastern and northeastern Texas. Fusconaia askewi was locally very abundant in Village Creek (Neches River basin), Neches, Sabine, Trinity and Angelina (Neches River basin) rivers, and in the Big Cypress Bayou (Red River basin). On average, F. askewi was the third most abundant species, and the number of live F. askewi collected at a particular site, on average, comprised $22 \%$ of the total number of all live mussels found at that site. Average density in mussel aggregations was $6.7 \mathrm{~m}^{-2}$ (Table 3). Sites with the greatest abundance were on Village Creek and the Neches and Sabine rivers. The most typical substrate for the species was sand, then a mixture of sand and silt, and gravel with sand. Average shell length of live F. askewi was $59.2 \pm 0.6 \mathrm{~mm}$ (mean \pm standard error here and elsewhere unless noted). Based on the presence of juveniles (Figure 5), the populations in East Texas were reproducing (shell length varied from 17 to $90 \mathrm{~mm}$ ). Nevertheless we failed to find $F$. askewi in several waterbodies belong to the species' former distribution range: in the San Jacinto River, its tributaries, and in Lake Houston, as well as in its historical location in Kickapoo Creek (North of Brownsboro, Henderson Co. [34] (Figure 4). Likewise, we did not find the species in any of the 6 reservoirs on the Trinity River and its tributaries. Our surveys also confirmed that F. askewi has been extirpated from Lanana and Bonita creeks (type localities for F. lananensis).
Only one dead shell and one valve of mussels identified as F. flava were found during our surveys, at two sites in the Sulphur River (Red River drainage), in Red River County and in Delta/Hopkins counties. Live individuals resembling $F$. flava have recently been collected in the East Fork of the Trinity River approximately $70 \mathrm{~km}$ from Dallas [54]. Mussels from the Sulphur River and the Trinity River have not been genetically tested yet.

\section{Pleurobema riddellii}

During our surveys, we found 132 live $P$. riddellii at 10 sites in 5 Texas counties (Anderson, Angelina, Cherokee, Hardin, and Nacogdoches), in the Neches, and Angelina rivers, and in Village Creek (Figure 6B, Table 3). Average density of $P$. riddellii was $1.9 \mathrm{~m}^{-2}$, and the species was not dominant in local unionid assemblages (the average relative abundance of $P$. riddellii was $5 \%$, Table 3). Most often $P$. riddellii was found in sand, silty sand, and sometimes in a mixture of sand and clay. Mean and median $P$. riddellii length were $52.4 \pm 1.1 \mathrm{~mm}$, range - 39-82 $\mathrm{mm}$ (Figure 5). The largest density was found in the Neches River south of Neches (Anderson Co.) in sand and gravel; this population had many juveniles ( $<25 \mathrm{~mm}$ long) in 2009 (Barclay unpublished data).

\section{Habitat requirements}

We found that $F$. askewi and $P$. riddellii have similar distribution (Table 3) and very similar habitat requirements. All these species were found exclusively in lotic waters, in relatively shallow areas (at 0.2 - $1.5 \mathrm{~m}$ depth), 
Table 2 Percent differences in nad1 sequence for Fusconaia species

\begin{tabular}{|c|c|c|c|c|c|c|c|c|c|c|}
\hline & $\begin{array}{c}\text { F. askewi } \\
3391\end{array}$ & $\begin{array}{c}\text { F. askewi } \\
3392\end{array}$ & $\begin{array}{l}\text { F. askewi } \\
\text { Sab1 }\end{array}$ & $\begin{array}{l}\text { F. askewi } \\
\text { Sab2 }\end{array}$ & $\begin{array}{l}\text { F. askewi } \\
\text { Sab5 }\end{array}$ & $\begin{array}{c}\text { F. askewi } \\
\text { TS219 }\end{array}$ & $\begin{array}{c}\text { F. askewi } \\
\text { TS233 }\end{array}$ & F. burkei & F. cerina & \\
\hline F. askewi 3392 & 0.24 & & & & & & & & & \\
\hline F. askewi Sab1 & 3.85 & 3.84 & & & & & & & & \\
\hline F. askewi Sab2 & 3.80 & 3.79 & 0.26 & & & & & & & \\
\hline F. askewi Sab5 & 3.00 & 2.99 & 1.04 & 1.02 & & & & & & \\
\hline F. askewi TS219 & 3.10 & 3.07 & 1.18 & 1.18 & 0.33 & & & & & \\
\hline F. askewi TS233 & 3.48 & 3.47 & 1.59 & 1.58 & 0.79 & 0.51 & & & & \\
\hline F. burkei & 2.39 & 2.39 & 3.34 & 3.10 & 2.58 & 2.51 & 3.19 & & & \\
\hline F. cerina & 1.37 & 1.24 & 3.96 & 4.04 & 3.24 & 3.07 & 3.60 & 2.45 & & \\
\hline F. cor & 4.68 & 4.66 & 6.06 & 5.77 & 5.04 & 6.12 & 5.93 & 4.34 & 4.28 & \\
\hline F. cuneolus & 4.51 & 4.49 & 6.23 & 6.12 & 5.57 & 6.11 & 6.29 & 4.01 & 4.62 & \\
\hline F. escambia & 2.71 & 2.58 & 3.97 & 3.92 & 3.38 & 3.43 & 3.88 & 0.63 & 3.00 & \\
\hline F. flava & 0.49 & 0.61 & 3.43 & 3.39 & 2.59 & 2.91 & 3.07 & 2.55 & 1.49 & \\
\hline $\begin{array}{l}\text { F. lananensis } \\
\text { TS129 TS179 }\end{array}$ & 2.71 & 2.69 & 0.91 & 0.90 & 0.13 & 0.17 & 0.66 & 2.71 & 3.12 & \\
\hline F. lananensis TS203 & 2.85 & 2.83 & 1.04 & 1.02 & 0.25 & 0.17 & 0.79 & 2.89 & 3.25 & \\
\hline F. masoni & 2.55 & 2.54 & 4.17 & 4.17 & 3.34 & 3.24 & 3.92 & 2.32 & 2.81 & \\
\hline F. ozarkensis & 4.38 & 4.34 & 5.50 & 5.15 & 4.61 & 5.19 & 4.86 & 4.53 & 4.69 & \\
\hline F. subrotunda & 5.52 & 5.50 & 7.56 & 7.42 & 6.50 & 6.68 & 7.07 & 5.35 & 5.66 & \\
\hline F. subrotunda PA I & 4.75 & 4.72 & 6.43 & 6.35 & 5.52 & 5.55 & 5.96 & 4.70 & 5.06 & \\
\hline \multirow[t]{2}{*}{ F. subrotunda PA s } & 4.85 & 4.84 & 6.30 & 6.21 & 5.39 & 5.56 & 5.69 & 5.70 & 5.21 & \\
\hline & F. cor & F. cuneolus & F. escambia & F. flava & $\begin{array}{l}\text { F. lananensis } \\
\text { TS129 TS179 }\end{array}$ & $\begin{array}{l}\text { F. lananensis } \\
\text { TS203 }\end{array}$ & F. masoni & F. ozarkensis & F. subrotunda & $\begin{array}{c}\text { F. subrotunda } \\
\text { PA I }\end{array}$ \\
\hline F. cuneolus & 4.33 & & & & & & & & & \\
\hline F. escambia & 4.50 & 4.17 & & & & & & & & \\
\hline F. flava & 4.50 & 4.66 & 2.82 & & & & & & & \\
\hline $\begin{array}{l}\text { F. lananensis } \\
\text { TS129 TS179 }\end{array}$ & 5.33 & 5.15 & 3.44 & 2.32 & & & & & & \\
\hline $\begin{array}{l}\text { F. lananensis } \\
\text { TS203 }\end{array}$ & 5.54 & 5.36 & 3.59 & 2.46 & 0.12 & & & & & \\
\hline F. masoni & 5.07 & 5.07 & 3.08 & 2.41 & 3.21 & 3.34 & & & & \\
\hline F. ozarkensis & 6.18 & 5.67 & 5.00 & 4.23 & 4.33 & 4.49 & 5.32 & & & \\
\hline F. subrotunda & 6.17 & 5.16 & 5.51 & 5.67 & 6.17 & 6.39 & 6.21 & 7.04 & & \\
\hline $\begin{array}{l}\text { F. subrotunda } \\
\text { PA I }\end{array}$ & 6.19 & 5.18 & 5.24 & 4.85 & 5.21 & 5.36 & 5.71 & 6.68 & 1.26 & \\
\hline $\begin{array}{l}\text { F. subrotunda } \\
\text { PA s }\end{array}$ & 6.21 & 5.68 & 5.62 & 4.97 & 5.08 & 5.21 & 5.85 & 6.57 & 1.30 & 1.11 \\
\hline
\end{tabular}

and the most preferable substrates for both F. askewi and $P$. riddellii were sand, and combinations of sand with gravel and silt. Total dissolved solids among waterbodies studied varied from 0.10 to $0.15 \mathrm{~g} / \mathrm{L}$, turbidity from 18.9 to 66.9 ed. NTU, pH - from 6.38 to 8.21. The lowest $\mathrm{pH}$ was recorded in Village Creek (average of 4 measurements in 2005 and 2007: 6.64 \pm 0.24 (standard deviation), minimal $6.38 \pm 0.12$ ) and in Sandy Creek $(6.69 \pm 0.006)$. Minimal $\mathrm{pH}$ value for the studied rivers and creeks recorded from 1973 to 2009 was 4.8 (4.8 for
Village Creek, 5.4 for the Angelina River, 5.6 for the Neches River, and 5.7 for Attoyac Bayou; data from the Texas Commission on Environmental Quality database (TCEQ Data Management and Analysis, Water Quality Planning Division), measured 4-12 times a year). This low $\mathrm{pH}$ caused heavy erosion of $F$. askewi shells, as it was previously recorded for Corbicula fluminea inhabiting acidic waters (streams with $\mathrm{pH}$ 5.6) [55]. In a few extreme cases, shells were eroded to the extent that the mussels' soft tissues were visible. 


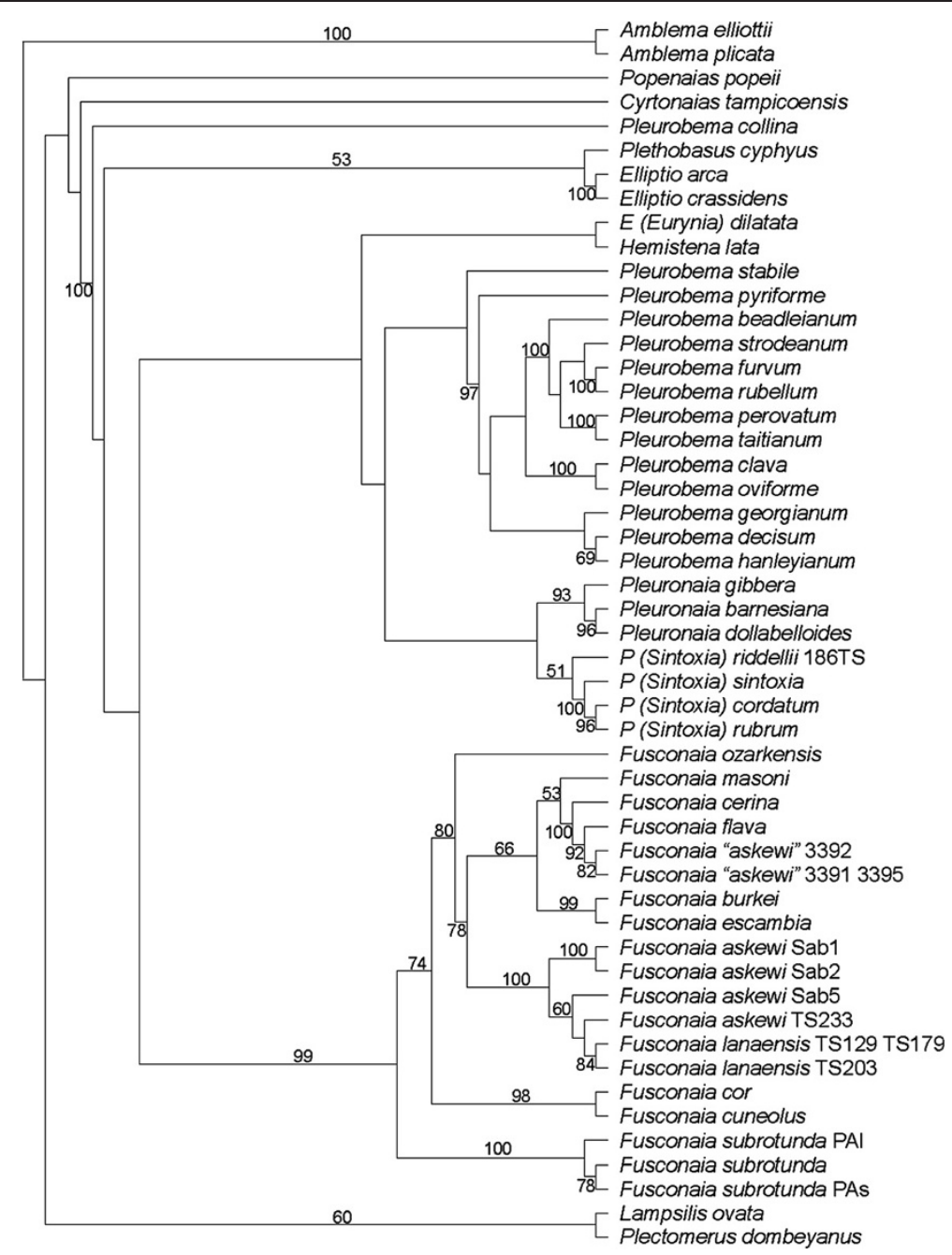

Figure 1 Strict consensus cladogram, combined cox 1 and nad 1 data, with jackknife percentages shown if over $\mathbf{5 0 \%}$. See text for discussion.

\section{Discussion}

Our surveys documented the current distribution and change in historical range, densities, and preferred habitat of rare Texas species. Genetic analysis revealed that: (1) F. lananensis is not a valid species; (2) it is likely that only one Fusconaia species (F. askewi) is currently found in East Texas; (3) the presence of F. flava in East Texas is unlikely, however the species may still persist in the Red River basin and upper Trinity River; (4) P. riddellii was well-separated from $F$. askewi and instead grouped with the P. sintoxia clade.

\section{Genetic analysis}

We found that the specimens from the Sabine and Neches drainages were genetically distinct from all other currently recognized Fusconaia species, as well as from the unusual sequences obtained by Burdick and White [17], and represented a distinct species. The relatively low percent difference from $F$. burkei reflects the shorter sequence for $F$. burkei, which consistently has a low difference from other sequences. Apart from it, all other Fusconaia cox 1 sequences differed from $F$. askewi and $F$. lananensis by more than 3.5 times as much as the largest difference within the $F$. askewi-F. lananensis group. In contrast, putative $F$. askewi sequences from the Calcasieu River in Louisiana matched closely sequences for $F$. flava, strongly suggesting that this population belongs in $F$. flava rather than $F$. askewi. The Calcasieu River runs between the Mississippi (specifically, the Red River) and the Sabine drainages, so faunal exchange could occur in either direction. Study of additional populations would be necessary to determine whether $F$. askewi is also present in the Calcasieu system or anywhere else east of the Sabine drainage.

All analyses strongly supported a group of Fusconaia lananensis and $F$. askewi (excluding the Calcasieu 


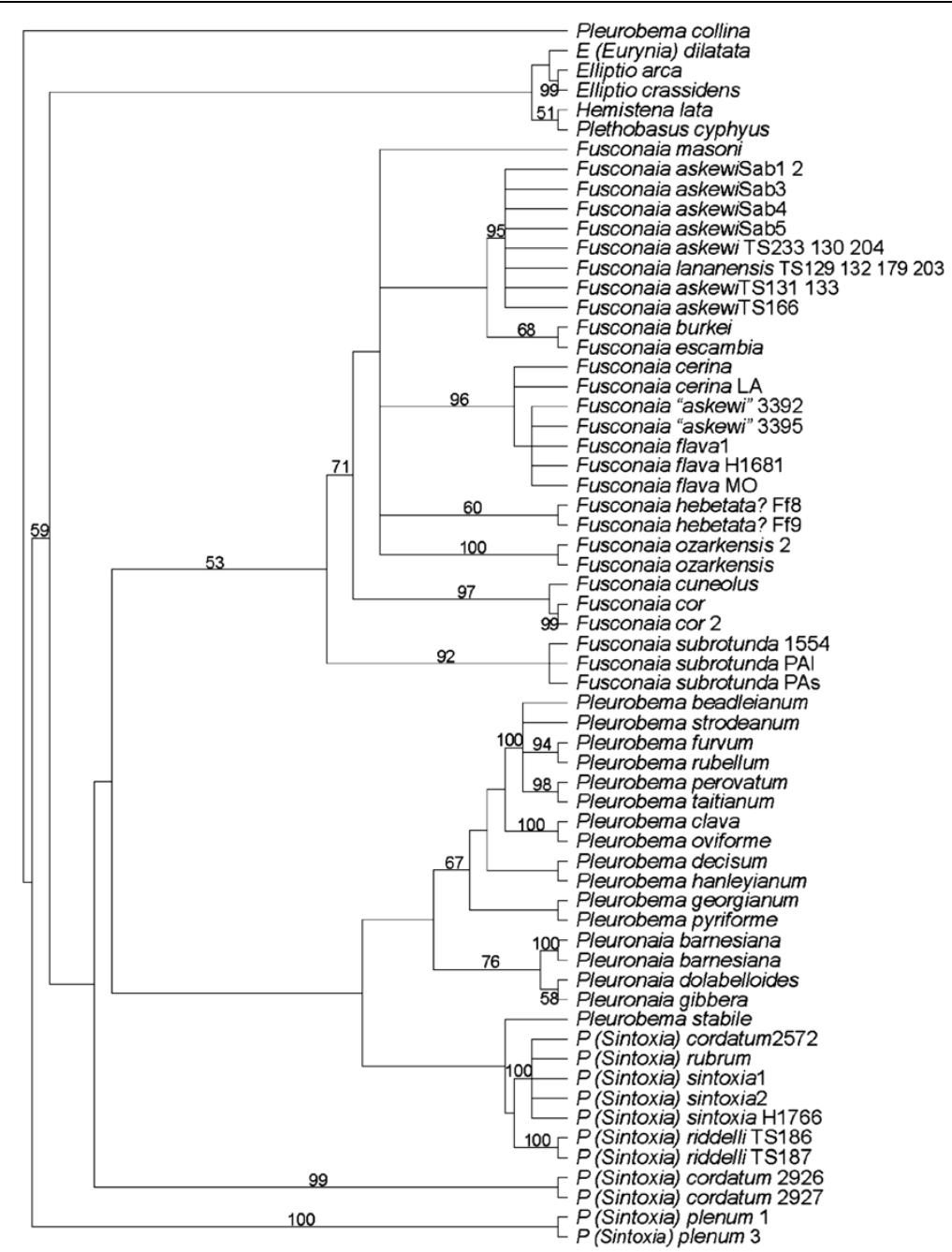

Figure 2 Strict consensus cladogram, cox 1 data, with jackknife percentages shown if over $50 \%$.

specimens). None of the analyses separated F. askewi from F. lananensis. Along with the low percentage difference (especially within the Neches drainage) and presence of morphologically intermediate specimens, this suggests that the $F$. lananensis is a subjective junior synonym of $F$. askewi. The distinguishing features noted by Frierson [36] would represent individual variation. Conversely, the specimens from the Calcasieu drainage are consistently strongly supported as closely related to F. flava and F. cerina. Current molecular data do not clearly distinguish between F. cerina and F. flava [17,47], so the Calcasieu population should probably be regarded as representing F. flava. The variations between Figures 1, 2, 3 show that relationships within Fusconaia are not wellresolved. Although the support is not strong, all analyses agree that F. subrotunda is basal, followed by a clade of F. cor and F. cuneolus. The remaining Fusconaia species, including $F$. askewi and F. lananensis, form a group with generally poorly resolved internal relationships. Thus,
F. askewi and F. lananensis clearly belong in Fusconaia, are distinct from other currently recognized species (except each other), and are most closely related to the $F$. cerina-F. flava group, the F. escambia-F. burkei group, F. masoni, F. ozarkensis, and the unidentified flava-like Fusconaia from the Ozark region (hebetata?). Support for the genus Fusconaia is modest in the cox 1 only analysis (perhaps due to the partial sequences) but very high in the others. However, relationships of Fusconaia to other genera of Pleurobemini are poorly resolved, and the weakly supported relationships between genera are not consistent between analyses.

Pleurobema riddellii shows consistent but weakly supported affinity for members of the subgenus Sintoxia-P. sintoxia, $P$. rubrum, and $P$. cordatum. However, the cox 1 analysis shows that other specimens identified as P. cordatum are more distantly related to this group. This may reflect the difficulties of identifying species in the $P$. cordatum group. Ongoing genetic work on this group [56] shows 


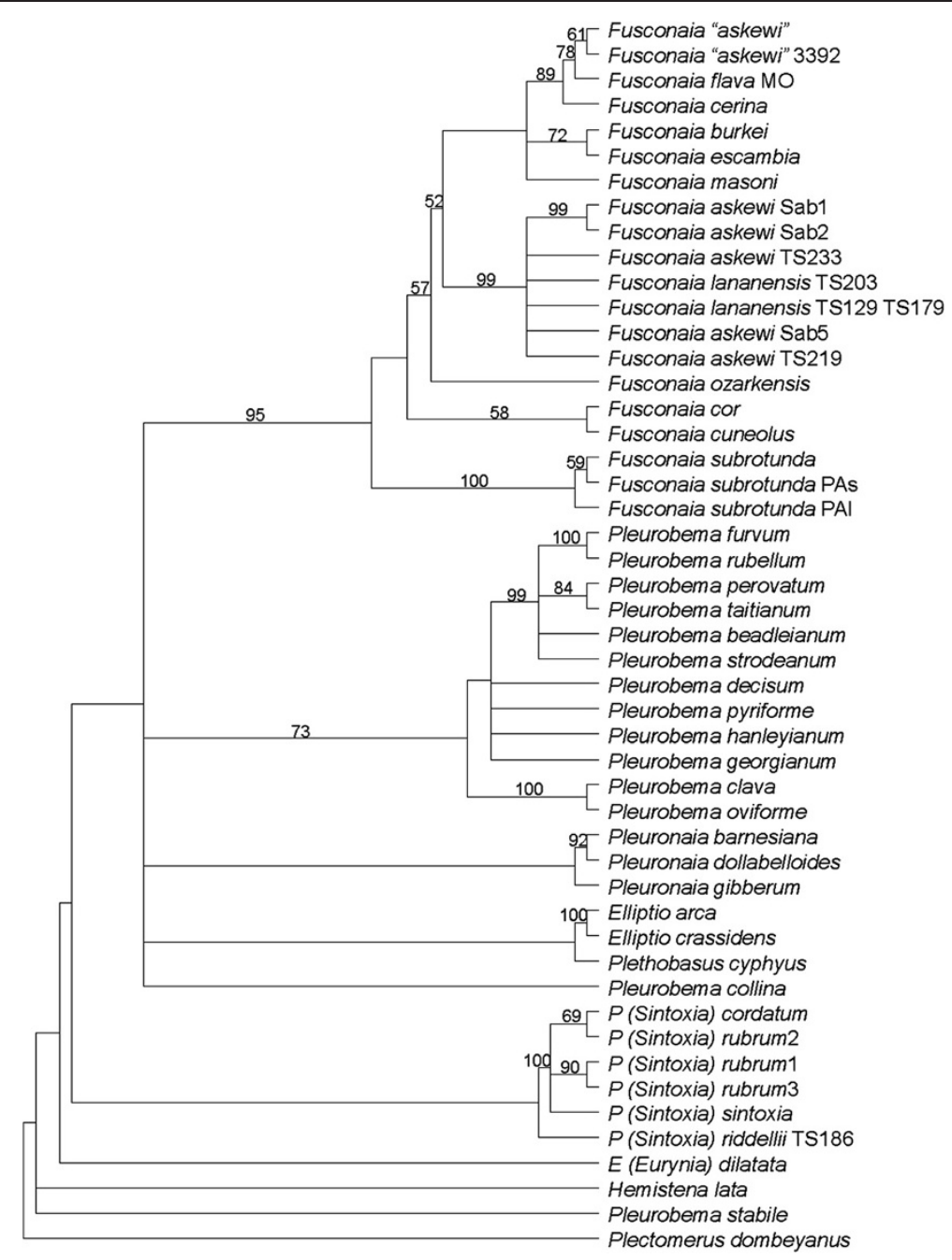

Figure 3 Strict consensus cladogram, nad1 data, with jackknife percentages shown if over $50 \%$.

further complications, but the morphological similarities of $P$. riddellii to the $P$. cordatum group [57] supports a relationship. Additionally, the only species of Pleurobema that occur in the lower Mississippi drainage are from the P. cordatum group [13], so the relationship also makes biogeographic sense.

At least four names older than F. askewi are available for Fusconaia species west of the Mississippi, besides F. flava, which was described from the Ohio drainage but occurs also in the upper Mississippi and west of it. Fusconaia ozarkensis (Call) is genetically and morphologically distinctive, but the remaining species have all been synonymized with or confused with F. flava: Fusconaia fulgidus (Lea), from the Red River at Alexandria, Louisiana; F. hebetata (Conrad), from Missouri (unfortunately, no information on which drainage); F. chunii (Lea), from the Trinity River at Dallas, Texas; and F. friersoni (Wright), from Bayou Pierre in the Red River system, De Soto Parish, Louisiana.
Although the first three are generally regarded as synonyms of F. flava [16], as older names they would have priority over F. askewi; F. friersoni was published just before $F$. askewi, but appears to be a synonym of $P$. riddellii instead [49]. Burdick and White [17] sampled one population from the lower Red River drainage near Alexandria and found it genetically similar to F. flava. The present results for the Calcasieu system also suggest that $F$. flava occurs in the lower Red River system. Graf and Cummings [57] suggested that $F$. hebetata might be a valid species. Study of the populations in the Ozark region, building on the work of Utterback [58] and Graf [16], should determine whether the conchological variation in populations in this region can be correlated with the genetic divergence found by Burdick and White [17]. If so, F. hebetata and other names based on material from the Ozark region can be assigned to the appropriate population. However, as Burdick and White's [17] sequences are quite distinct from those 
Table 3 Historical and current distribution, and densities of Fusconaia askewi and Pleurobema riddellii in Texas

\begin{tabular}{|c|c|c|}
\hline Habitat characteristics & F. askewi & P. riddellii \\
\hline Distribution (Literature data) & $\begin{array}{c}\text { Angelina River, Attoyac Bayou, Bonita Creek, Lanana } \\
\text { Creek, Cypress Bayou, Cypress River, Big Lake, Big Creek, } \\
\text { Chambers Creek, Lake Fork Creek, Navasota River, } \\
\text { Kickapoo Creek, Neches River, Sabine River, Sandy } \\
\text { Creek, San Jacinto River, Trinity River, Village Creek and } \\
\text { tributaries }[14,15,24,26-29,31,34-36,49-53]\end{array}$ & $\begin{array}{c}\text { Angelina River, Big Lake, Kickapoo Creek, Sabine } \\
\text { River, San Jacinto River, Trinity River, Village Creek } \\
\text { and tributaries, Chambers Creek } \\
{[15,24,30,31,34,35,37]}\end{array}$ \\
\hline Current distribution (Our data) & $\begin{array}{l}\text { Angelina River (27), Attoyac Bayou (25), Sandy Creek } \\
\text { (52), Big Cypress Bayou (2), Neches River (274), Sabine } \\
\text { River (129), Trinity River (36), Village Creek (386) }\end{array}$ & $\begin{array}{c}\text { Angelina River (9), Neches River (86), Village Creek } \\
\text { (37) }\end{array}$ \\
\hline Density, $\mathrm{m}^{-2}$ & $6.7 \pm 12.8$ (data from 7 sites, 89 quadrats total) & $1.9 \pm 1.2$ ( 5 sites, 49 quadrats) \\
\hline Relative abundance, $\%$ & $22(1-58)$ & $5(1-13)$ \\
\hline
\end{tabular}

Amount of live molluscs found in each waterbody during this study is in parentheses. Densities in mussel assemblages (mean \pm standard deviation) were calculated using $0.25 \mathrm{~m}^{2}$ quadrats. Relative species abundance (mean and range in parentheses) was calculated as a percentage of live specimens belong to this species collected at a particular site from the total number of all live mussels found at this site, and used as an indicator of the species' dominance in mussel assemblages.

obtained in the present study for F. askewi, it seems safe to assume that $F$. hebetata is not applicable to the present material from Texas and Louisiana.

This leaves F. chunii as a possible senior synonym of Fusconaia askewi and F. lananensis. Howells et al. [14] synonymized $F$. chunii with $F$. flava, but Graf [16] identified their illustrated $F$. "flava" from Texas as different from true $F$. flava. We were unable to obtain live specimens from the Red River systems in Texas for genetic analyses. Specimens suggestive of $F$. flava from the Neches drainage,
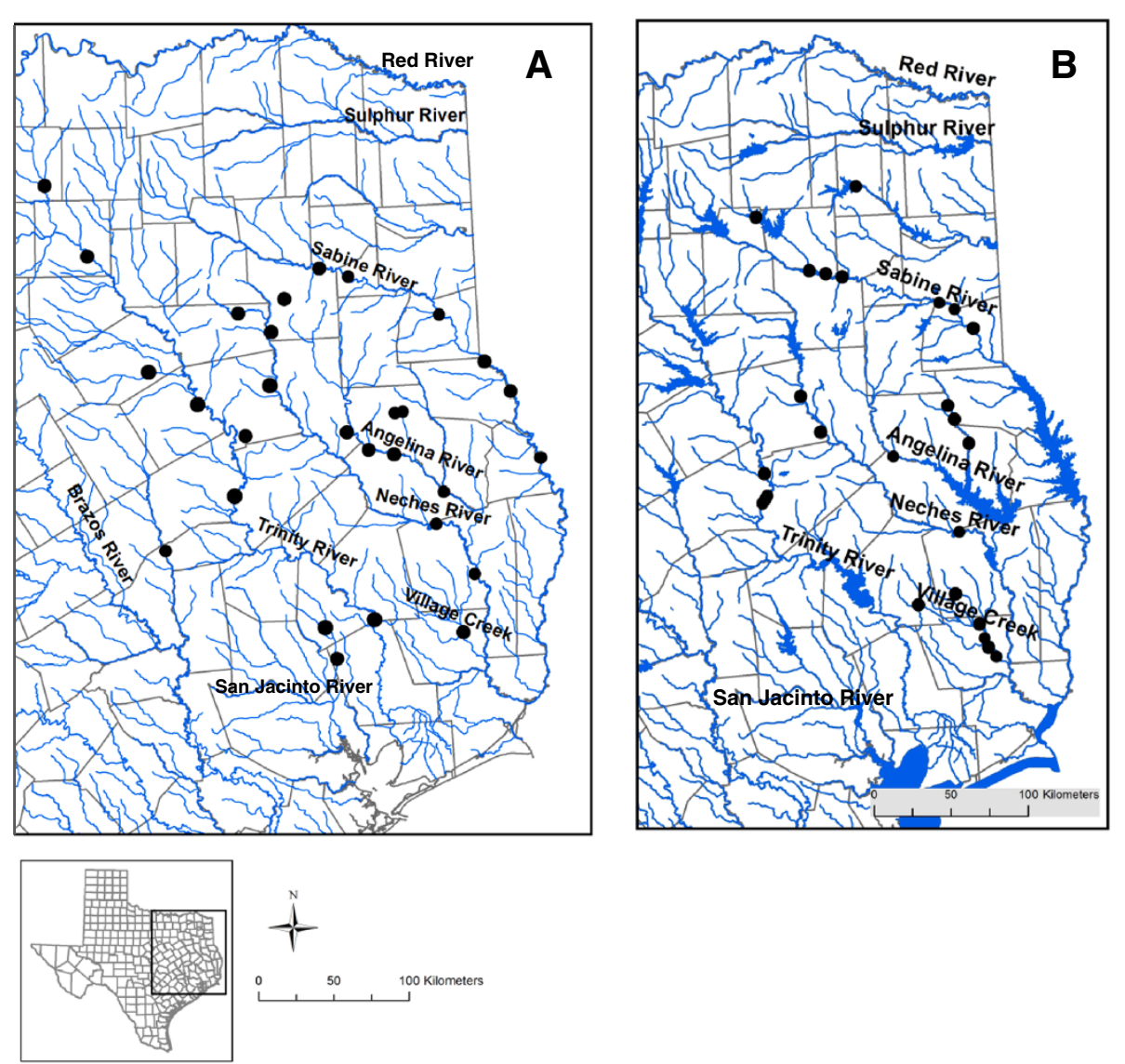

Figure 4 Historical (before 1940, A) and current (1990-present, B) distribution of Fusconaia askewi in East Texas. Historical data are from Pilsbry [38], Singley [37], Frierson [24], Frierson [36], Frierson [25], Strecker [34], and Bachtel [35]. Current data include authors' data and literature records [15,26-33]. 


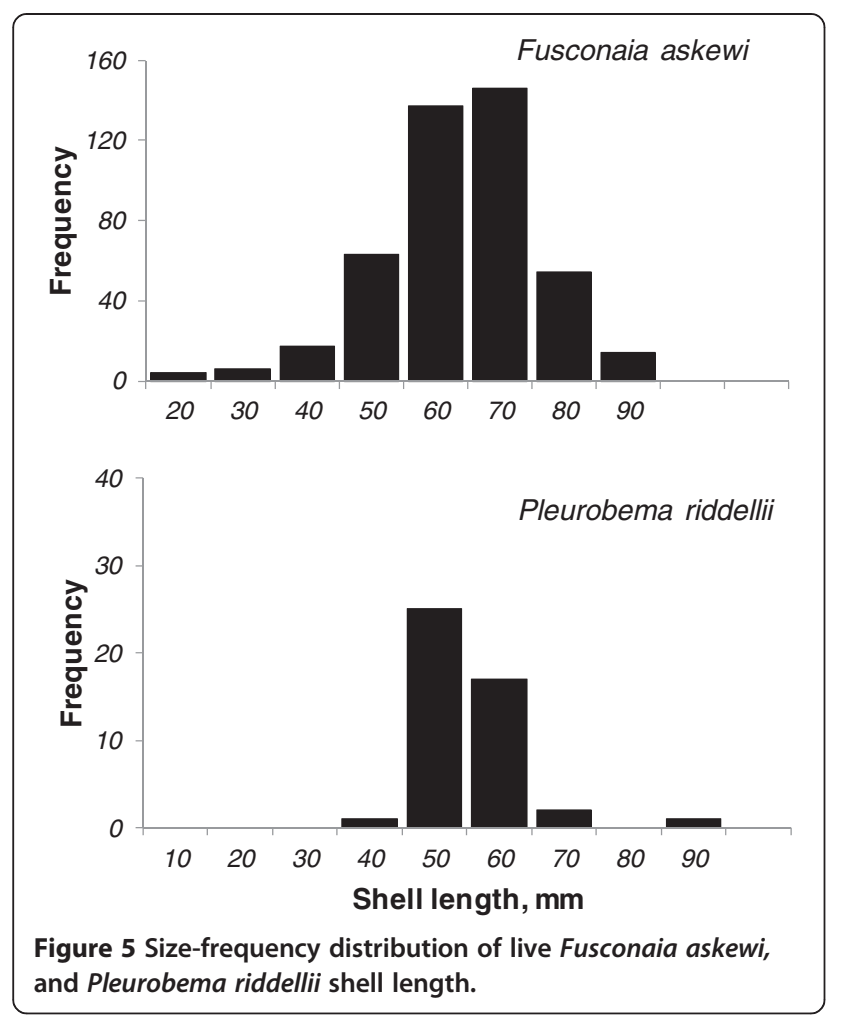

sampled in the present study, placed genetically with F. askewi. The Trinity system is immediately west of the Neches and the headwaters of the Sabine, and could easily have exchanged species through stream capture or other interaction. Stream capture occurs when a stream previously connected to one drainage system becomes connected to another, eventually becoming a part of the second drainage system [59]. However, the Trinity River headwaters also adjoin the Red River system in northern Texas. The lower Red River system in Louisiana has F. flava [17]. To the north of the Red River system is the Arkansas system, and the possible $F$. hebetata haplotype occurs in an Arkansas tributary. The picture is thus very complex, but it seems most likely that $F$. chunii is a senior synonym of $F$. askewi.

In contrast to the varying opinions on Fusconaia species, authors have generally agreed on recognizing Pleurobema riddellii. However, there has been some uncertainty about its affinities [13]. The present results provided moderate support for Frierson's [60] suggestion that it is relatively closely related to the Pleurobema cordatum group. Most other work on this group has focused exclusively on the Mississippi drainage species and does not mention $P$. riddellii.

\section{Distribution, densities, size structure, and habitat Fusconaia askewi}

F. askewi is a regional endemic, historically known from the Sabine, Neches, Trinity and San Jacinto rivers in
Texas [38] (Table 3, Figure 4A), and from Louisiana [13]. Simpson [50] lists F. askewi range from western Louisiana to eastern Texas with type locality as Village Creek, Hardin Co., and the Sabine River, Texas. Strecker [34] recorded this species in the Angelina, Sabine and Navasota rivers, and from Kickapoo Creek. Neck [49] reported $F$. askewi as locally common, but noted that the status over its entire range was unclear. During our surveys we found live F. askewi in four drainages in eastern and northeastern Texas (Table 3, Figure 4B). This species was locally abundant, often dominated mussel assemblages, and several populations were reproducing. The most typical substrate for the species was sand, sand and silt, and gravel with sand.

Fusconaia lananensis was described by Frierson in 1901 [36], after the first account of Texas unionids was published [37]. Frierson collected 200 specimens of F. lananensis from Lanana and Bonita creeks near Nacogdoches, Texas [36]. Strecker [34] found live F. lananensis in Lanana Creek, and in the San Jacinto River. In 1990s, few live mussels were found in Attoyac Bayou and Sandy Creek (Angelina River drainage) [51], and 36 live mussels were found in Village Creek [15]. We found live mussels that fit the description of "F. lananensis" in several waterbodies in East Texas. Due to the similar shell morphologies of $F$. askewi and F. lananensis, field identification between the two nominal species was very challenging, which is not surprising considering their genetic similarity. Frierson [36] reports that "Q[uadrula] lananensis is closely allied to Q. askewi Marsh, both by its conchological and anatomical characteristics. It may be differentiated from that shell by being longer, more compressed, more oblique, and its shell is never so inflated and thickened in front as askewi and not so acutely angled on the posterior ridge. Internally, lananensis is rose-colored nearly invariably and the color is uniformly spread over its surface. Askewi is mostly white, and, when colored (pink) the color is almost always confined exterior to the pallial line. Finally, Q. askewi never possess those peculiar pearly excrescences, which seem to belong to lananensis". We observed several patterns in nacre coloration of Fusconaia from East Texas drainages. There were three forms recorded in the Neches drainage: with entirely white nacre, solid rose/pink, and the form with the pink extrapallial ring described by Frierson [36]. Practically the entire Fusconaia population in the Sabine River had white nacre, while almost none of the Trinity Fusconaia showed the pink extrapallial ring (most of them were white, and a few - solid pink). Therefore, we saw the same features (e.g., pearly excrescences and rose-colored nacre) in both species, with many intermediate forms that were impossible to separate, suggesting that F. lananensis may not be a valid species. This suggestion was supported by our genetic analysis. Habitat and substrate preferences of both Fusconaia spp. were found to be similar as well. 

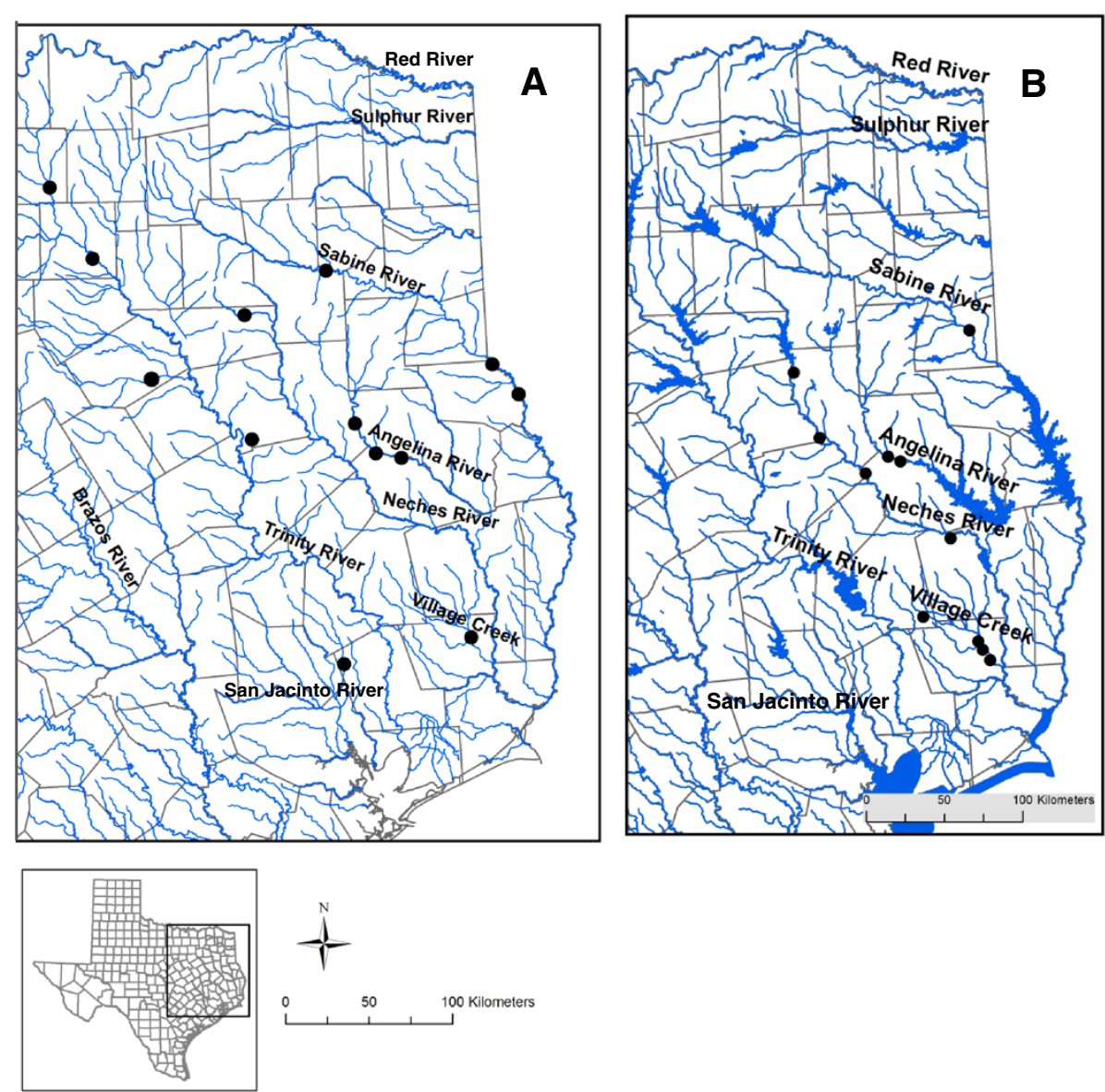

Figure 6 Historical (before 1940, A) and current (1990-present, B) distribution of Pleurobema riddellii in Texas. Historical data are from Frierson [24], Strecker [34], Bachtel [35]. Current data include authors' data and literature records [15,30,31].

\section{Pleurobema riddellii}

This species is a regional endemic, found in Texas and Louisiana [14,51]. Singley [37] recorded $P$. riddellii in Village Creek only; Strecker recorded the species from the Angelina, Sabine, San Jacinto and Trinity rivers in East Texas [34] (Figure 6A). NatureServe reports a substantial recent decline in this species [61]. During our surveys, we found a total of 132 live P. riddellii in one East Texas river basin (the Neches River), but not at the sites we surveyed on the Trinity River (Figure 6B). Pleurobema riddellii has probably been extirpated from the San Jacinto River. This species was not locally abundant, and not dominant in mussel assemblages. Although most populations were comprised of older animals, several populations were reproducing. Pleurobema riddellii was found exclusively in lotic waters, in relatively shallow areas, most often in sand, or in a mixture of sand, gravel and silt.

\section{Conservation priorities}

\section{Fusconaia askewi}

The American Fisheries Society considers F. askewi and $F$. lananensis to be of special concern [4], and both species are currently listed as state threatened [8] and as near-threatened by the IUCN [62]. Our recent surveys classified these species as rare (species that were found at low densities in 1 to 9 Texas waterbodies) based on their occurrence and density [5]. The U.S. Fish and Wildlife Service found that substantial scientific information was presented indicating that listing of $F$. lananensis may be warranted due to the present or threatened destruction, modification, or curtailment of its habitat or range [10], and a status review for the species was initiated in 2009. However, our study suggested that $F$. lananensis is not a valid species and it is likely that only one Fusconaia species (F. askewi, senior synonym $F$. chunii) is currently present in East Texas, thus simplifying conservation efforts. Although we found that $F$. askewi still inhabits four river basins in eastern and northeastern Texas and can be locally abundant, its distribution range has been reduced in the last 80 years: the species have been extirpated from a number of waterbodies in Texas, including Lanana and Bonita creeks, the San Jacinto and Navasota rivers, and Kickapoo Creek (Figure 4). The distribution of F. askewi in the Trinity River has been also reduced in the 
last 40 years (Figure 4). The species has been extirpated from much of its former range in the upper Trinity River north of SR-7 (Leon/Houston Counties), and appears to be completely absent from the river south of Lake Livingston (D. Barclay, personal observations).

\section{Pleurobema riddellii}

This species was found in only one East Texas drainage (the Neches River), and at very low densities. During the last 80 years the distribution range of $P$. riddellii has been dramatically reduced, and this species has been extirpated from several East Texas waterbodies where it occurred historically (Figure 6). Notably, some of these waterbodies (e.g., San Jacinto River) that lost both F. askewi and P. riddellii, are the most highly populated in Texas [19]. At the beginning of $20^{\text {th }}$ century, the San Jacinto River was a home for 29 unionid species, but due to extensive mining, deforestation, damming and urbanization, it lost almost $70 \%$ of its former unionid diversity [19]. The U.S. Fish and Wildlife Service found that listing of $P$. riddellii as threatened or endangered may be warranted due to the present or threatened destruction, modification, or curtailment of its habitat or range resulting from general human modification of the water and adjacent land, siltation, impoundments, and water pollution $[9,10]$, however it is currently listed as threatened only at the state level [8].

Currently East Texas has predominantly forested watersheds with little urbanization, both factors being important for maintaining the health of aquatic environments [63]. Not surprisingly, this part of Texas is the hotspot for the state's unionid diversity where almost every river supports from 17 to 28 species [19]. However, Texas is one of the fastest growing states in the nation. The urban population in Texas nearly doubled in the last 30 years [64], with a $21 \%$ increase in urbanization since 1990 [65]. Along with growing urbanization, it is predicted that $>20$ million ha of U.S. forest will be developed over the next 50 years $[66,67]$, and $>11 \%$ of private forests, mostly in the South, could experience substantial increases in housing density by $2030[68,69]$. Considering growing development and water demand, the best measure for conservation of both $F$. askewi and $P$. riddellii would be by controlling deforestation, urbanization and water diversion in East Texas watersheds, and particularly the Neches River.

\section{Additional file}

Additional file 1: Sequences used for genetic analysis [42,47,48,56,70-78].

\section{Competing interests}

The authors declare that they have no competing interests.

\section{Acknowledgements}

Funding for this study was provided by the U.S. Fish and Wildlife Service' State Wildlife Grant Program through the Texas Parks and Wildlife
Department (2004-2010: PIs LEB, AYK; 2011-2012: PIs LEB, AYK, and M. E. May, M. D. Warriner, and B. Gottfried, TPWD). The ABI 3100 automated sequencer was funded by a NSF equipment grant to C. Lydeard, R. Mayden, M. Powell, and P. Harris (DBI-0070351). We would like to acknowledge the help of Vadim and Dimitry Karatayev, Jesse, David, and Regan Barclays, and Daniel Bennett (TPWD) in data collection, and Sandy Birnbaum (Texas Natural Diversity Database manager) for help with GIS maps. The TNT program was available with the sponsorship of the Willi Hennig Society.

\section{Author details}

${ }^{1}$ Great Lakes Center, Buffalo State College, 1300 Elmwood Ave, Buffalo, NY 14222, USA. ${ }^{2}$ The Research Foundation of The State University of New York, Buffalo State College, Office of Sponsored Programs, Buffalo, NY 14222, USA ${ }^{3}$ The Paleontological Research Institution, 1259 Trumansburg Road, Ithaca, NY 14850, USA. ${ }^{4} 7219$ FM 2781, Kennard, TX 75847, USA.

\section{Authors' contributions}

LEB and AYK designed the study and surveyed sites state-wide. DB surveyed additional sites in East Texas. DC carried out the molecular genetic studies and their interpretation. LEB, AYK and DC led, and DB edited the writing. All authors read and approved the final manuscript.

Received: 14 February 2012 Accepted: 25 June 2012

Published: 25 June 2012

\section{References}

1. Régnier $C$, Fontaine $B$, Bouchet $P$ : Not knowing, not recording, not listing: numerous unnoticed mollusk extinctions. Conserv Bio/ 2009, 23:1214-1221.

2. Bogan AE: Freshwater bivalve extinctions (Molusca: Unionidae): a search for causes. Am Zool 1993, 33:599-609.

3. Lydeard C, Clark SA, Perez KE, Cowie RH, Ponder WF, Bogan AE, Bouchet P, Gargominy O, Cummings KS, Frest TJ, et al: The Global Decline of Nonmarine Mollusks. Bioscience 2004, 54:321-330.

4. Williams JD, Warren ML Jr, Cummings KS, Harris JL, Neves RJ: Conservation status of freshwater mussels of the United States and Canada. Fisheries 1993, 18(9):6-22

5. Burlakova LE, Karatayev AY, Karatayev VA, May ME, Bennett DL, Cook MJ: Endemic species: contribution to community uniqueness, effect of habitat alteration, and conservation priorities. Biol Conserv 2011, 144:155-165.

6. States of the Union: Ranking America's Biodiversity. NatureServe 2002, http://www.natureserve.org/Reports/stateofunions.pdf.

7. Dahm CN, Edwards RJ, Gelwick FP: In Rivers of North America. Edited by Arthur CB, Colbert EC. Burlington: Academic; 2005:180-228.

8. Texas Parks and Wildlife Department: Threatened and endangered nongame species. Chapter 65. Wildlife Subchapter G. 31 TAC $\$ 65.175$. Adopted rules. Texas Regist 2010, 35:251. Texas Secretary of State, 2010.

9. U.S. Fish and Wildlife Service: Endangered and Threatened Wildlife and Plants; 90-Day Finding on Petitions to List Nine Species of Mussels from Texas as Threatened or Endangered with Critical Habitat. Proposed Rules. Fed Regist 2009, 74(239):66261-66271. Department of the Interior, Fish and Wildlife Service, 50 CFR Part 17, 2009.

10. U.S. Fish and Wildlife Service: Endangered and Threatened Wildlife and Plants; Partial 90-Day Finding on a Petition to List 475 Species in the Southwestern United States as Threatened or Endangered With Critical Habitat. Proposed Rules. Fed Regist 2009, 74(240):66866-66905. Department of the Interior, Fish and Wildlife Service, 50 CFR Part 17, 2009.

11. Williams JD, Mulvey M: Recognition of freshwater mussel taxa: A conservation challenge. In Principles of Conservation Biology. Edited by Meffe GK, Carroll CR. Sunderland: Sinauer Associates; 1994:57-58.

12. Lydeard C, Roe KJ: Phylogenetic systematics: The missing ingredient in the conservation of freshwater unionid bivalves. Fisheries 1998, 23:16-17.

13. Vidrine MF: The Historical Distributions of Freshwater Mussels in Louisiana. Eunice, Louisiana: Gail Q. Vidrine Collectibles; 1993.

14. Howells RG, Neck RW, Murray HD: Freshwater Mussels of Texas. Austin TX: Texas Parks and Wildlife Press; 1996.

15. Bordelon VL, Harrel RC: Freshwater mussels (Bivalvia: Unionidae) of the Village Creek drainage basin in southeast Texas. Texas J Sci 2004, 56:63-72.

16. Graf DL: Morphology, Zoogeography, and Taxonomy of Fusconaia flava (Rafinesque) (Mollusca: Bivalvia: Unionidae) in the Upper Mississippi, Great Lakes, and Nelson River Basins. MS thesis: Northeastern University; 1997. 
17. Burdick RC, White MM: Phylogeography of the Wabash pigtoe, Fusconaia flava (Rafinesque, 1820) (Bivalvia: Unionidae). J Mollusc Stud 2007, 73:367-375.

18. Johnson Rl: Zoogeography of North American Unionacea (Mollusca: Bivalvia) north of the maximum Pleistocene glaciation. Bull Mus Comp Zool 1980, 149:77-189

19. Burlakova LE, Karatayev AY, Karatayev VA, May ME, Bennett DL, Cook MJ: Biogeography and conservation of freshwater mussels (Bivalvia: Unionidae) in Texas: patterns of diversity and threats. Divers Distrib 2011, 17:393-407.

20. Strayer DL, Claypool S, Sprague SJ: Assessing unionid populations with quadrats and timed searches. In Conservation and Managenment of Freshwater Mussels II (Initiatives for future): Proceedings of an Upper Mississippi River Conservation Committee (UMRCC) Symposium; 16-18 October 1995, St. Louis, Missouri. Edited by Cummings KS, Buchanan AC, Mayer CA, Naimo TJ. Rock Island, Illinois: Upper Mississippi River Conservation Committee; 1997:163-169.

21. Vaughn CC, Taylor CM, Eberhard KJ: A comparison of the effectiveness of timed searches vs. quadrat sampling in mussel surveys. In Proceedings of an Upper Mississippi River Conservation Committee (UMRCC) Symposium, 16-18 October 1995 St. Louis, Missouri. Edited by Cummings KS, Buchanan AC, Mayer CA, Naim TJ. St. Louis, MO: Upper Mississippi River Conservation Committee, Rock Island, Illinois; 1997:157-162.

22. Dunn HL: Development of strategies for sampling freshwater mussels (Bivalvia: Unionidae). In Freshwater Mollusk Symposia Proceedings Part II Proceedings of the 1st Freshwater Mollusk Conservation Society Symposium. Edited by Tankersley RA, Warmolts DI, Watters GT, Armitage BJ, Johnson PD, Butler RS. Columbus, OH: Ohio Biological Survey; 2000:161-167.

23. Strayer DL, Smith DR: A guide to sampling freshwater mussel populations. Maryland: Bethesda; 2003.

24. Frierson LS: Among the Unios of the Sabine River. Nautilus 1899, 13(7):79-81.

25. Frierson LS: Collecting Unionidae in Texas and Louisiana. Nautilus 1902, 16(4):37-40.

26. Howells RG: Distributional surveys of freshwater bivalves in Texas: progress report for: Management Data Series 1996a, 120. Austin, TX: Texas Parks and Wildlife Department; 1994.

27. Howell RG: Distributional surveys of freshwater bivalves in Texas: progress report for: Management Data Series 1997, 144. Austin, TX: Texas Parks and Wildlife Department; 1996.

28. Ford NB, Nicholson ML: A survey of freshwater mussels of the Old Sabine Wildlife Management Area, Smith County, Texas. Tex J Sci 2006, 58:243-254

29. Ford NB, Gullett J, May ME: Diversity and abundance of unionid mussels in three sanctuaries on the Sabine River in northeast Texas. Tex J Sc 2009, 61:279-294.

30. Ford NB, Williams L, Williams M: Surveys of rare freshwater unionids and fish in the upper reaches of the Sabine River to gather population information on threatened species. State Wildlife Grant Report to Texas Parks and Wildlife Department. 2010. http://texasmussels.files.wordpress.com/2010/11/ford-upper-sabine.pdf.

31. Vidrine MF: Fresh-water mussel-mite and mussel-Ablabesmyia associations in Village Creek, Hardin County, Texas. Proc La Acad Sci 1990, 53:1-4.

32. Howells RG: Distributional surveys of freshwater bivalves in Texas: progress report for: Management Data Series 19966, 125. Austin, TX: Texas Parks and Wildlife Department; 1995.

33. Howells RG: Distributional surveys of freshwater bivalves in Texas: progress report for: Management Data Series 2003, 214. Austin, TX: Texas Parks and Wildlife Department; 2002.

34. Strecker JK: The distribution of the naiades or pearly freshwater mussels of Texas. Baylor Univ Mus Bull 1931, 2:69.

35. Bachtel HJ: Freshwater mussels of East Texas. Austin State Teachers College, Nacogdoches, Texas: MS thesis. Stephen F; 1940.

36. Frierson LS: A new Unio from Texas. Nautilus 1901, 15:75-76. plate.

37. Singley JA: Contributions to the Natural History of Texas. Part I. Texas Mollusca. A preliminary list of the land, fresh water, and marine Mollusca of Texas. In Fourth Annual Report of the Geological Survey of Texas 1982. Part 1. Edited by Dumble ET, Austin TX.: Department of Agriculture, Insurance, Statistics, and History; 1893:299-343.

38. Pilsbry HA: Critical notes on eastern Texas Unionidae. Nautilus 1891, 5:74-77.

39. Folmer $\mathrm{O}$, Hoeh WR, Black MB, Vrijenhoek RL: DNA primers for amplification of mitochondrial cytochrome C oxidase subunit I from metazoan invertebrates. Mol Mar Biol Biotechn 1994, 3:294-299.

40. Buhay JE, Serb JM, Dean CR, Parham Q, Lydeard C: Conservation genetics of two endangered unionid bivalve species, Epioblasma florentina walkeri and E. capsaeformis (Unionidae: Lampsilini). J Mollusc Stud 2002, 68:385-391.

41. Serb JM, Lydeard C: Complete mtDNA sequence of the North American freshwater mussel, Lampsilis ornata (Unionidae): An examination of the evolution and phylogenetic utility of mitochondrial genome organization in Bivalvia (Mollusca). Molec Biol Evol 2003, 20:1854-1866.

42. Serb JM, Buhay JE, Lydeard C: Molecular systematics of the North American freshwater bivalve genus Quadrula (Unionidae: Ambleminae) based on mitochondrial ND1 sequences. Molec Phylog Evol 2003, 28:1-11.

43. Walker JM, Bogan AE, Bonfiglio EA, Campbell DC, Christian AD, Curole JP, Harris JL, Wojtecki RJ, Hoeh WR: Primers for amplifying the hypervariable, male-transmitted COII-COI junction region in Amblemine freshwater mussels (Bivalvia: Unionoidea: Ambleminae). Molec Ecol Notes 2007, 7:489-491.

44. Carpenter JM, Wheeler WC: Towards simultaneous analysis of morphological and molecular data in Hymenoptera. Zoo/ Scr 1999, 28:251-260.

45. Hall TA: BioEdit: A user-friendly biological sequence alignment editor and analysis program for Windows 95/98/NT. Nucleic Acids Symp Ser 1999, 41:95-98.

46. Goloboff P, Farris J, Nixon K: TNT, a free program for phylogenetic analysis. Cladistics 2008, 24:774-786.

47. Campbell DC, Lydeard C: Molecular Systematics of Fusconaia (Bivalvia: Unionidae: Ambleminae). Am Malacol Bull 2012, 30:1-17.

48. Bogan AE, Hoeh WR: On becoming cemented: evolutionary relationships among the genera in the freshwater bivalve family Etheriidae (Bivalvia: Unionoida). In The Evolutionary Biology of the Bivalvia. Edited by Harper EM, Taylor JD, Crame JA. London: The Geological Society; 2000:159-168. Special Paper no. 177

49. Neck RW: Restricted and declining nonmarine molluscs of Texas. Technical Series 1984, 34:1-17. Austin, TX: Texas Parks and Wildlife Department.

50. Simpson CT: A Descriptive Catalogue of the Naiades, or Pearly Fresh-Water Mussels. Detroit. Michigan: B. Walker; 1914.

51. Howells RG, Mather CM, Bergmann JAM: Conservation status of selected freshwater mussels in Texas. In Conservation and Managenment of Freshwater Mussels II (Initiatives for future): Proceedings of a UMRCC Symposium; 1997. Edited by Cummings KS, Buchanan AC, Mayer CA, Naimo TJ. St. Louis, MO: Upper Mississippi River Conservation Committee: 1997:117-129.

52. Shira AF: The mussel fisheries of Caddo Lake and the Cypress and Sulphur rivers of Texas and Louisiana. U.S: Bureau of Fisheries Economic Circular; 1913:6.

53. Shafer D, Miller A, Farr M: A survey of freshwater mussels (Family: Unionidae) in the proposed Red River Waterway, Texas and Louisiana, between Shreveport, Louisiana and Daingerfield, Texas. August 27 to September 2. Vicksburg, MS. U. S. Army Engineers Waterways Experimental Station: Environmental Laboratory; 1992.

54. Randklev CR, Wolverton S, Lundeen BJ, Kennedy JH: A paleozoological perspective on unionid (Mollusca: Unionidae) zoogeography in the upper Trinity River basin, Texas. Ecol Appl 2010, 20:2359-2368.

55. Kat PW: Shell dissolution as a significant cause of mortality for Corbicula fluminea (Bivalvia: Corbiculidae) inhabiting acidic waters. Malacol Rev 1982, 15:129-134.

56. Morrison C, Jones J, Eackles M, Johnson N, King T: Phylogenetic relationships among members of the tribe Pleurobemini: Preliminary results. In Meeting Program and Abstracts, $4^{\text {th }}$ Biennial Symposium, Freshwater Mollusk Conservation Society: May 15-18, 2005. St. Paul, MN: Freshwater Mollusk Conservation Society; 2005:51. http://www.ncbi.nlm.nih. gov/nuccore/EF619920.1.

57. Graf DL, Cummings KS: Review of the systematics and global diversity of freshwater mussel species (Bivalvia: Unionoida). J Mollusc Stud 2007, 73:291-314.

58. Utterback Wl: The Naiades of Missouri. Reprinted from Amer Midl Natur 1916, 4:1-200

59. Hayes CW, Campbell MR: The relation of biology to physiography. Science 1900, 12(291):131-133

60. Frierson LS: A classified and annotated checklist of the North American naiades. Waco, Texas: Baylor University Press; 1927.

61. NatureServe Explorer: An online encyclopedia of life. http://www.natureserve. org/explorer. 
62. International Union for Conservation of Nature: Guidelines for Using the IUCN Red List Categories and Criteria. Version 8.0. IUCN Standards and Petitions Working Group. 2010. http://intranet.iucn.org/webfiles/doc/SSC/RedList/ RedListGuidelines.pdf.

63. Dudgeon D, Arthington AH, Gessner MO, Kawabata ZI, Knowler DJ, Leveque C, Naiman RJ, Prieur-Richard AH, Soto D, Stiassny MLJ, Sullivan CA: Freshwater biodiversity: importance, threats, status and conservation challenges. Biol Rev 2006, 81:163-182.

64. US Department of Agriculture: USDA Economic Research Service. http://www. ers.usda.gov/statefacts/tx.htm.

65. US Department of Agriculture: USDA Urban Forest Data for Texas. http://nrs. fs.fed.us/data/urban/state/?state $=$ TX.

66. Alig RJ, Plantinga AJ: Future forestland area: Impacts from population growth and other factors that affect land values. J For 2004, 102:19-24.

67. Alig RJ: U.S. land-use changes involving forests: trends and projections. In Transactions of the 72nd North American Wildlife and Natural Resources Conference. Portland, OR: Wild life Management Institute, Gardners, PA; 2007:96-108. http://www.fsl.orst.edu/lulcd/Publicationsalpha_files/ Alig_2007_JSF.pdf.

68. Thompson J: Society's choices: land use changes, forest fragmentation, and conservation. PNW Science Findings 2006, 88:1-5.

69. White EM, Alig RJ, Stein SM, Mahal LG, Theobald DM: A sensitivity analysis of "Forests on the Edge: Housing Development on America's Private Forests". Portland, OR: U.S: Department of Agriculture, Forest Service, Pacific Northwest Research Station; 2009. General Technical Report PNW-GTR-792.

70. Campbell DC, Serb JM, Buhay JE, Roe KJ, Minton RL, Lydeard C: Phylogeny of North American Amblemines (Bivalvia, Unionoida): prodigious polyphyly proves pervasive across genera. Invertebr Biol 2005, 124:131-164.

71. Chapman EG, Piontkivska H, Walker JM, Stewart DT, Curole JP, Hoeh WR: Extreme primary and secondary protein structure variability in the chimeric male-transmitted cytochrome $\mathrm{c}$ oxidase subunit II protein in freshwater mussels: Evidence for an elevated amino acid substitution rate in the face of domain-specific purifying selection. BMC Evol Biol 2008, 8:165-181.

72. Graf DL, Foighil DÓ: The evolution of brooding characters among the freshwater pearly mussels (Bivalvia: Unionoidea) of North America. J Mollusc Stud 2000, 66:157-170.

73. Campbell DC, Johnson PD, Williams JD, Rindsberg AK, Serb JM, Small KK, Lydeard C: Identification of "extinct" freshwater mussel species using DNA barcoding. Mol Ecol Resour 2008, 8:711-724.

74. Gangloff MM, Mahon AR, Siefferman LM, Campbell DC, Halanych KM: Molecular systematics of the morphologically plastic freshwater bivalve genus Elliptio (Unionidae). In review: Molecular systematics of the morphologically plastic freshwater bivalve genus Elliptio (Unionidae). In review; Data available: http://www.ncbi.nlm.nih.gov/nuccore/183988743.

75. Lydeard C, Minton RL, Williams JD: Prodigious Polyphyly in Imperiled Freshwater Pearly-Mussels (Bivalvia: Unionidae): A Phylogenetic Test of Species and Generic Designations. In The Evolutionary Biology of the Bivalvia. Edited by Harper EM, Taylor JD, Crame JA. London: The Geological Society; 2000:145-158. Special Paper no. 177.

76. Roe K, Hartfield PD, Lydeard C: Phylogenetic analysis of the threatened and endangered superconglutinate-producing mussels of the genus Lampsilis (Bivalvia: Unionidae). Mol Ecol 2001, 10:2225-2234.

77. Campbell DC, Lydeard C: The genera of Pleurobemini (Bivalvia: Unionidae: Ambleminae). Am Malacol Bull 2012, 30:19-38.

78. Petty MA, Johnson NA, Hallerman EM, Neves RJ: Genetic characterization of the endangered James spinymussel, Pleurobema collina (Bivalvia: Unionoida). Unpublished. Some data available at: http://www.ncbinlm.nih.gov/nuccore/ EF619920.1.

doi:10.1186/2046-9063-8-12

Cite this article as: Burlakova et al.: Distribution, genetic analysis and conservation priorities for rare Texas freshwater molluscs in the genera Fusconaia and Pleurobema (Bivalvia: Unionidae). Aquatic Biosystems 2012 8:12.

\section{Submit your next manuscript to BioMed Central and take full advantage of:}

- Convenient online submission

- Thorough peer review

- No space constraints or color figure charges

- Immediate publication on acceptance

- Inclusion in PubMed, CAS, Scopus and Google Scholar

- Research which is freely available for redistribution

Submit your manuscript at www.biomedcentral.com/submit 